\title{
Status of vitamin D, paratharmone and serum calcium levels in perimenopausal women and their mutual correlation
}

\author{
Shashi Singh ${ }^{1}$, Parul Sinha ${ }^{1 *}$, Uma Gupta ${ }^{3}$, Gupta N. K. ${ }^{2}$, Anand Srivastava ${ }^{3}$ \\ ${ }^{1}$ Department of Obstetrics and Gynecology, ${ }^{2}$ Department of Medical Education, Era's Lucknow Medical College, \\ Lucknow, Uttar Pradesh, India \\ ${ }^{3}$ Department of Respiratory Medicine, KGMU, Uttar Pradesh, India
}

Received: 13 September 2016

Accepted: 08 October 2016

*Correspondence:

Dr. Parul Sinha,

E-mail: drparulanad@gmail.com

Copyright: $\odot$ the author(s), publisher and licensee Medip Academy. This is an open-access article distributed under the terms of the Creative Commons Attribution Non-Commercial License, which permits unrestricted non-commercial use, distribution, and reproduction in any medium, provided the original work is properly cited.

\begin{abstract}
Background: The present study was carried out with an aim to assess Vitamin D, parathyroid hormone and calcium status in perimenopausal women and to find out their mutual correlation.

Methods: The present work was carried out on in the Department of Obstetrics and Gynaecology, in collaboration with Department of Biochemistry at Era's Lucknow Medical College and Hospitals, Lucknow, U.P. 80 healthy females aged 40-50 years were included in the study. Serum vitamin D, parathyroid hormone and calcium levels were assessed. Data was analyzed using ANOVA and Pearson correlation coefficient.

Results: Osteopenia and osteoporosis was seen in $33(41.3 \%)$ and $21(26.3 \%)$ women respectively, 50 (62.5\%) women had S. vitamin D levels $<30 \mathrm{ng} / \mathrm{ml}$, a total of $43(53.8 \%)$ women had parathyroid hormone $<75 \mathrm{pg} / \mathrm{ml}$. No association between BMD status, parathyroid hormone, S. calcium levels and vitamin D levels was observed ( $>>0.05)$. Correlation between Vitamin D levels and Parathyroid hormone levels was weak and not significant.

Conclusions: The findings of present study highlighted that perimenopausal phase should be regarded as a transition phase where a lot of physiological changes take place resulting in bone mineral density loss and fall in serum hormonal, vitamin and mineral levels. Owing to tremendous continuing changes the relationship between these parameters is vitiated and does not show a systematic change.
\end{abstract}

Keywords: Bone mineral density, Parathyroid hormone, Perimenopausal, S. calcium, S. vitamin D

\section{INTRODUCTION}

Perimenopause is defined as "the time preceding the normal menopause during which declining ovarian function causes oligomenorrhea or dysfunctional uterine bleeding, symptoms of estrogen deficiency and elevated gonadotrophins." It is a progressive endocrinologic continuum leading to a final cessation on menstruation. ${ }^{2}$ According to WHO, "perimenopause should include the period immediately before the menopause (when the endocrinological, biological and clinical features of approaching menopause commence) and the first year after menopause."
In a nutshell, perimenopause is a unique hormonal transition. It is demonstrably more complex than it was previously understood to be; it is clearly not a time of "declining ovarian function." Instead, dynamic perimenopausal ovaries produce erratic and high estradiol levels and rarely ovulate normally. These changes in hormonal levels manifest themselves in most aspects of a woman's health and may present as conditions involving almost every system of her body.

A plenty of physiological, hormonal and physical changes start to take place in the peripmenopausal phase of a woman's life. Most noticeable physical changes that 
make onset during perimenopausal phase include decay in bone mineral density, which has been shown to be dependent on calcium content, which in turn is affected by declining $25(\mathrm{OH})_{2}$ Vitamin D levels and parathyroid hormone. $^{3-5}$ Hence, perimenopausal phase, which is considered to be a precursor of decline in bone-mineral density must also have relative effect on the serum calcium, parathyroid hormone and $25(\mathrm{OH})_{2}$ vitamin $\mathrm{D}$ levels. Considering the importance and relevance of this relationship, the present study was carried out to assess the bone mineral density, Vitamin D, parathyroid hormone and calcium status in perimenopausal women and to find out a plausible relationship between them.

\section{METHODS}

The present work was carried out in the Department of Obstetrics and Gynaecology, in collaboration with Department of Biochemistry at Era's Lucknow Medical College and Hospitals, Lucknow, U.P. over a period of eighteen months starting from January 2014 to June 2015 .

A total of 80 women aged 40 to 50 years not taking vitamin $\mathrm{D}$ and calcium preparation for last 6 months and undergoing perimenopausal changes for 3-4 years period before menopause were enrolled in the study after taking informed consent. Clearance was taken from the institutional ethical committee. Women with any chronic disease such as diabetes mellitus, hypertension, hyperthyroidism, asthma, chronic Kidney disease, epilepsy, HIV and women outside the selected age group who have attained menopause were excluded from the assessment.

The questionnaire was filled to get the information about social status, education, exercise, sun-exposure and diet. The blood samples were collected for serum Vitamin D, parathyroid hormone and calcium.

Vitamin D levels were assessed using DIAsource $25 \mathrm{OH}$ Vitamin D Total ELISA kit. Vitamin D levels <10 ng/ml were considered to indicate vitamin D deficiency, levels in the range $10-29 \mathrm{ng} / \mathrm{ml}$ were considered to indicate vitamin D insufficiency.

Parathyroid hormone levels were assessed quantitatively using Biomerica Intact-PTH ELISA reader. iPTH levels $>75 \mathrm{pg} / \mathrm{ml}$ were considered to indicate hyperparathyroidism.

Bone mineral density was assessed using DEXA Bone densitometer. Values below -2SD were considered to indicate osteopenia whereas values below -3SD were considered to indicate osteoporosis.

Data was analysed using Statistical Package for Social Sciences (SPSS) version 15.0. Analysis of variance and Pearson correlation coefficient were calculated. The confidence level of the study was kept at $95 \%$, hence ' $p$ ' value $<0.05$ indicated a statistically significant association.

\section{RESULTS}

Age of women enrolled in the study ranged from 42 to 50 years. Mean age was $42.35 \pm 2.23$ years. Exactly half the women were overweight and obese $(42.50 \%$ and $7.50 \%)$. There were $17(21.5 \%)$ women who were underweight. Only $26(32.5 \%)$ had normal BMD. Maximum had osteopenia $(n=33 ; 41.3 \%)$. There were 21 (26.3\%) women who had osteoporosis. Vitamin D deficiency was found in 3 (3.8\%) women. Majority (58.8\%) had vitamin $\mathrm{D}$ levels in the range of $10-29 \mathrm{ng} / \mathrm{ml}$ thus indicating vitamin D insufficiency. A total of 30 (37.5\%) had vitamin D levels in normal range. Serum ionic parathyroid hormone (iPTH) levels indicative of hyperparathyroidism were seen in 37 (46.2\%). Mean serum calcium levels were $8.62 \pm 1.23 \mathrm{mg} / \mathrm{ml}$ (Table 1).

Table 1: Profile of women enrolled in the study.

\begin{tabular}{|c|c|c|}
\hline SN & Characteristic & Statistic \\
\hline 1. & Mean Age \pm SD (Range) in years & $\begin{array}{l}45.35+2.23 \\
(42-50)\end{array}$ \\
\hline \multirow{5}{*}{2.} & BMI Category & \\
\hline & Underweight $\left(<18.5 \mathrm{~kg} / \mathrm{m}^{2}\right)$ & $17(21.5 \%)$ \\
\hline & $\begin{array}{l}\text { Normal weight }(18.5-24.9 \\
\left.\mathrm{kg} / \mathrm{m}^{2}\right)\end{array}$ & $23(28.75 \%)$ \\
\hline & Overweight $\left(25.0-29.9 \mathrm{~kg} / \mathrm{m}^{2}\right)$ & $34(42.50 \%)$ \\
\hline & Obese $\left(>30 \mathrm{~kg} / \mathrm{m}^{2}\right)$ & $6(7.50 \%)$ \\
\hline \multirow{4}{*}{3.} & BMD Status & \\
\hline & Normal & $26(32.5 \%)$ \\
\hline & Osteopenia & $33(41.3 \%)$ \\
\hline & Osteoporosis & $21(26.3 \%)$ \\
\hline \multirow{4}{*}{4.} & $25(\mathrm{OH})_{2}$ Vitamin D status & \\
\hline & $<10 \mathrm{ng} / \mathrm{ml}$ (Deficient) & $3(3.8 \%)$ \\
\hline & $10-29 \mathrm{ng} / \mathrm{ml}$ (Insufficient) & $47(58.8 \%)$ \\
\hline & $30-100 \mathrm{ng} / \mathrm{ml}$ (Normal) & $30(37.5 \%)$ \\
\hline \multirow{3}{*}{5 . } & Ionic Parathyroid level (iPTH) & \\
\hline & $<75 \mathrm{pg} / \mathrm{ml}$ & $43(53.8 \%)$ \\
\hline & $\begin{array}{l}>75 \mathrm{pg} / \mathrm{ml} \\
\text { (Hyperparathyroidism) }\end{array}$ & $37(46.2 \%)$ \\
\hline 6. & $\begin{array}{l}\text { Mean Serum Calcium levels } \\
(\mathrm{mg} / \mathrm{ml})\end{array}$ & $8.62 \pm 1.23$ \\
\hline
\end{tabular}

No significant association between BMD status and vitamin D, serum calcium and iPTH levels was observed ( $>0.05$ ) (Table 2).

No significant association vitamin D levels with serum calcium and iPTH levels was observed $(\mathrm{p}>0.05)$ (Table $3)$. 
Table 2: Association between BMD status and other study parameters.

\begin{tabular}{|c|c|c|c|c|c|c|}
\hline \multirow[t]{2}{*}{ BMD } & \multicolumn{2}{|c|}{$\begin{array}{l}\text { Vitamin D } \\
(\mathrm{ng} / \mathrm{ml})\end{array}$} & \multicolumn{2}{|c|}{$\begin{array}{l}\text { Calcium } \\
\text { (mg/ml) }\end{array}$} & \multicolumn{2}{|c|}{ iPTH (mg/ml) } \\
\hline & Mean & SD & Mean & SD & Mean & SD \\
\hline $\begin{array}{l}\text { Normal } \\
(\mathrm{n}=26)\end{array}$ & 22.75 & 8.08 & 8.48 & 1.26 & 115.76 & 99.79 \\
\hline $\begin{array}{l}\text { Osteopenic } \\
(\mathrm{n}=33)\end{array}$ & 27.36 & 8.73 & 8.71 & 1.25 & 90.26 & 64.57 \\
\hline $\begin{array}{l}\text { Osteoporotic } \\
(\mathrm{n}=21)\end{array}$ & 27.70 & 8.41 & 8.67 & 1.14 & 83.78 & 61.44 \\
\hline $\begin{array}{l}\text { Statistical } \\
\text { Analysis } \\
\text { (ANOVA) }\end{array}$ & \multicolumn{2}{|c|}{$\begin{array}{l}\text { 'F'=2.787; } \\
p=0.068\end{array}$} & \multicolumn{2}{|c|}{$\begin{array}{l}' F^{\prime}=0.262 \\
p=0.770\end{array}$} & \multicolumn{2}{|c|}{$\begin{array}{l}' F^{\prime}=1.204 \\
p=0.306\end{array}$} \\
\hline
\end{tabular}

Table 3: Association of parathyroid levels and Calcium levels with vitamin D levels in Study population.

\begin{tabular}{lllllll|}
$\begin{array}{l}\text { Vitamin } \\
\text { D } \\
(\mathbf{n g} / \mathrm{ml})\end{array}$ & \multicolumn{2}{l}{$\begin{array}{l}\text { Parathyroid level } \\
(\mathrm{pg} / \mathrm{ml})\end{array}$} & $\mathbf{M e a n}$ & SD & $\mathbf{3}$ & \multicolumn{3}{c|}{ Mean } & SD \\
\hline$<10$ & 3 & 171.90 & 118.50 & 3 & 8.97 & 1.22 \\
\hline $10-29$ & 47 & 85.81 & 59.03 & 47 & 8.68 & 1.25 \\
\hline $30-100$ & 30 & 106.62 & 94.38 & 30 & 8.49 & 1.19 \\
\hline & 'F' $=2.197 ; \mathrm{p}=0.118$ & 'F' $=0.340 ; \mathrm{p}=0.713$ \\
\hline
\end{tabular}

\section{DISCUSSION}

Loss in bone mineral density leading to conditions like osteopenia and osteoporosis in peri-menopausal women is a common problem associated with age with plenty of data in suppor. ${ }^{6-9}$ However, there is evidence that bone mineral density varies from one region of the world to another region of the world within same age-group for both the genders. ${ }^{10,11}$ Notwithstanding these differences, the association of osteoporosis and osteopenia among women is often associated with menopausal status and interestingly the age of menopause among western women is also stated to be higher as compared to that of women in Indian subcontinent. ${ }^{12-15}$

The prevalence of osteopenia and osteoporosis in current study was found to be $41.25 \%$ and $26.25 \%$ respectively (collectively $67.5 \%$ ). The prevalence of osteopenia and osteoporosis in perimenopausal age groups has been reported variedly in different case series. Prevalence of osteopenia in different studies ranges from $27.3 \%$ to $64.3 \%$ whereas prevalence of osteoporosis ranges from $4.1 \%$ to $26.25 \%$. The prevalence of osteopenia in present study is lower than that reported by Agarwal and Verma $(64.3 \%)$ however, prevalence of osteoporosis is higher than that reported by Agarwal and Verma (19\%). The reason for difference in prevalence of osteopenia and osteoporosis could be due to ethnic differences, age of women, nutritional and dietary status and method of estimation of BMD.
In present study, no significant association between serum vitamin $\mathrm{D}$, calcium and parathyroid hormone levels was observed with BMD status of women. One of the reasons for this could be the fact that prevalence of low BMD was quite high $(67.5 \%)$ and owing to hormonal changes particularly estrogen levels the usual CalciumVitamin D Parathyroid hormone endocrine axis was impaired and the relationship was crippled by the ageing and hormonal changes. One must not forget that vitamin $\mathrm{D}$, one of the most important components of CalciumVitamin D Parathyroid hormone endocrine axis plays an important role in the estrogen biosynthesis and owing to impaired estrogen production during perimenopausal women its bioavailability remains affected which ultimately affects the Calcium-Vitamin D Parathyroid hormone endocrine axis. ${ }^{16}$

In present study, vitamin $\mathrm{D}$ levels did not show a significant association with parathyroid hormone or calcium levels. Although an inverse relationship between vitamin $\mathrm{D}$ and parathyroid hormone levels is proposed by several workers, however, it is limited upto a certain level of vitamin D. ${ }^{17,18}$ The findings in present study also showed a similar situation. Moreover, perimenopausal stage being a transitory phase in which menopausal status is changing fast and affecting the established relationships as observed in pre- and post-menopausal women. Similar to results in present study, Brot et al, also failed to establish a significant association between vitamin $\mathrm{D}$ and parathyroid levels in perimenopausal women and attributed variances in vitamin D levels to a host of factors including dietary vitamin D intake, vitamin supplementation, sunlight exposure, and use of sun-bed. ${ }^{19}$ The calcium levels as observed in present study seemed to be affected by drop in estrogen production resulting in bone resorption and decreased calcium absorption and were not guided by usual 'Calcium-Vitamin D Parathyroid hormone endocrine axis. ${ }^{, 20}$ It is important to mention here that vitamin D levels remain unaffected with the perimenopausal status. Epstein et al, who studied the largest group of women, found that serum 1,25-(OH), D concentration increased up to age 65 years and then decreased. ${ }^{21}$ On the contrary most of the studies have indicated lower BMD and as such lower calcium levels in peri- and post-menopausal women and incidence of lower BMD to be increasing with age, thus indicating that though calcium levels are affected by menopausal status and age, vitamin D levels remain unaltered and unaffected by these changes for a long period even after menopause. ${ }^{23-25}$

The findings in present study are thus radical and show that during perimenopausal phase itself, the usual Calcium-Vitamin D Parathyroid hormone endocrine axis is vitiated which might be the reason for decay in bone mineral density leading to increase in prevalence of osteopenia and osteoporosis.

One of the limitations of present study was absence of a comparative group, either of pre- or post-menopausal 
women. In the absence of this group, the changes in calcium, vitamin D and parathyroid hormone vis-a-vis BMD status of the women could be studied only within perimenopausal phase. Considering the fact that perimenopausal phase is a transitory phase of life with a short span coupled with phenomenal hormonal changes in progress it is difficult to reach at a definitive conclusion and explaining the radical relationships as observed in present study.

\section{CONCLUSION}

The findings also suggest that the BMD vis-a-vis calcium, parathyroid hormone and vitamin $\mathrm{D}$ levels in perimenopausal are in a transition phase vitiating the normal relationship between them. Keeping in view the continuum of contemporary hormonal changes affecting the physical and physiological status of women, further studies to understand this relationship further are recommended.

\section{Funding: No funding sources}

Conflict of interest: None declared

Ethical approval: The study was approved by the Institutional Ethics Committee

\section{REFERENCES}

1. Nelson LM, Anasti JN, Flack MR. Premature ovarian failure. In: Adashi EY, Rock JA, Rosenwacks Z (eds) Reproductive Endocrinology Surgery and Technology. Lippincott-Raven Publishers, Philadelphia. 1996;1393-1410.

2. Menopausal Transition. In: Williams Gynecology. Editors Hoffman BL, Schorge JO, Schaffer JL, Halvorson LM, Bradshaw KD, Cunningham FG. 2nd Edition. McGraw Hill New York, 2012, pp. 554-580.

3. Holick MF. Sunlight and Vitamin D for bone health and prevention of autoimmune disease-cancers and cardiovascular diseases. Am J Clin Nutr. 2004;80(6):1678S-88S.

4. Harinarayan CV, Joshi SR. Vitamin D status in India- Its implications and Remedial measures. J Assoc Physicians India. 2009;57:40-8.

5. Dorner T, Weichselbaum E, Lawrence K, Stein KV, Rieder A. Austrian osteoporosis report: epidemiology, lifestyle factors, public health strategies. Wien Med Wochenschr. 2009;159(910):221-9.

6. Unni J, Garg R, Pawar R. Bone mineral density in women above 40 years. J Mid-life Health. 2010;1:19-22.

7. Limpaphayom KK, Taechakraichana N, Jaisamrarn U, Bunyavejchevin S, Chaikittisilpa S, Poshyachinda $\mathrm{M}$, et al. Prevalence of osteopenia and osteoporosis in Thai women. Menopause. 2001 Jan-Feb;8(1):65-9.

8. Pasco JA. Seeman E, Henry .MJ, Merriman EN, Nicholson GC, Kotowicz MA. The population burden of fractures originates in women with osteopenia, not osteoporosis. Osteoporos Int. 2006; 17:1404-9.

9. Zhou Y, Li Y, Zhang D, Wang J, Yang $\mathrm{H}$. Prevalence and predictors of osteopenia and osteoporosis in postmenopausal Chinese women with type 2 diabetes. Diabetes Research and Clinical Practice. 2010;90(3):261-9.

10. Holt G, Khaw KT, Reid DM, Compston JE, Bhalla A, Woolf AD. Prevalence of osteoporotic bone mineral density at the hip in Britain differs substantially from the US over 50 years of age: implications for clinical densitometry. BJR. 2002;75(897):736-42.

11. Sang JH, Hwang IC, Han HS, Lee W, Kim TH, Lee $\mathrm{HH}$, Chung SH, Shin KS. Prevalence of Osteoporosis and Osteopenia in Women in Gumi Gyeongbuk Province. J Korean Soc Menopause. 2012 Apr; 18(1): 28-35.

12. Lau EM, Lynn H, Woo J, Melton LJ. Areal and volumetric bone density in Hong Kong Chinese: a comparison with Caucasians living in the United States. Osteoporos Int. 2003;14:583-8.

13. Yahya S, Rehan N. Age, pattern and symptoms of menopause among rural women of Lahore. J Ayub Med Coll (Abbottabad). 2002;14:9-12.

14. Singh A, Kaur S, Walia I. A historical perspective on menopause and menopausal age. Bull Indian Inst Hist Med Hyderabad. 2002 Jul-Dec;32(2):121-35.

15. Kriplani A, Banerjee K. An overview of age of onset of menopause in northern India. Maturitas. 2005 Nov-Dec;52(3-4):199-204.

16. Kinuta K, Tanaka H, Moriwake T, Aya K, Kato S, Seino Y. Vitamin D is an important factor in estrogen biosynthesis of both female and male gonads. Endocrinology. 2000 Apr;141(4):1317-24.

17. Chapuy MC, Preziosi P, Maamer M, Arnaud S, Galan P, Hercberg S, et al. Prevalence of vitamin D insufficiency in an adult normal population. Osteoporos Int. 1997; 7:439-443.

18. Dawson-Hughes B, Harris SS, Dallal GE. Plasma calcidiol, season, and serum parathyroid hormone concentrations in healthy elderly men and women. Am J Clin Nutr. 1997;65:67-71.

19. Brot C, Vestergaard P, Kolthoff N, Gram J, Hermann $\mathrm{AP}$ and Sùrensen $\mathrm{OH}$. Vitamin $\mathrm{D}$ status and its adequacy in healthy Danish perimenopausal women: relationships to dietary intake, sun exposure and serum parathyroid hormone. British Journal of Nutrition. 2001;86(1):S97-103.

20. Piste P, Didwagh S, Mokashi A. Calcium and its role in Human Body. Int. J. Res. Pharmaceutical and Medical Sciences. 2013;4(2):659-68.

21. Epstein S, Bryce G, Hinman JW, Miller ON, Riggs BL, Hui SL, et al. The influence of age on bone mineral regulating hormones. Bone 1986; 7:421-5.

22. Smeets-Goevaers CG, Lesusink GL, Papapoulos SE, Maartens LW, Keyzer JJ, Weerdenburg JP, et al. The prevalence of low bone mineral density in Dutch perimenopausal women: the Eindhoven 
perimenopausal osteoporosis study. Osteoporos Int. 1998;8(5):404-9.

23. Bener A, Hammoudeh M, Zirie M, Heller RF. Is obesity a protective factor for osteoporosis? APLAR Journal of Rheumatology. 2005;8:32-8.

24. Gandhi AB, Shukla AKR. Evaluation of BMD of women above 40 years of age. J Obstet Gynecol India. 2005;55(3):265-7.
25. Agarwal T, Verma AK. Cross sectional study of osteoporosis among women. Medical Journal Armed Forces India. 2013;69:168-71.

Cite this article as: Singh $S$, Sinha $P$, Gupta U, Gupta NK, Srivastava A. Status of vitamin D, paratharmone and serum Calcium levels in perimenopausal women and their mutual correlation. Int J Reprod Contracept Obstet Gynecol 2016;5:4009-13. 